\title{
EVALUATION OF THE MOLLUSCICIDAL POTENTIAL OF HYDROALCOHOLIC EXTRACTS OF Jatropha gossypiifolia Linnaeus, 1753 ON Biomphalaria glabrata (Say, 1818)
}

Adalberto Alves PEREIRA FILHO, Clícia Rosane Costa FRANÇA, Dorlam's da Silva OLIVEIRA, Renato Juvino de Aragão MENDES, José de Ribamar Santos GONÇALVES \& Ivone Garros ROSA

\begin{abstract}
SUMMARY
The action of extracts from the stem, leaves, and fruit of Jatropha gossypiifolia on Biomphalaria glabrata was studied by analyzing survival, feeding capacity and oviposition ability. The extracts were obtained by macerating the plant parts in $92 \%$ ethanol, which were then evaporated until a dry residue was obtained and phytochemically studied. The molluscicidal activity on $B$. glabrata was investigated using the procedures recommended by WHO (1965). The amount of food ingested and oviposition were measured during each experiment. The extract of leaves from J. gossypiifolia was shown to be a strong molluscicidal agent, causing $100 \%$ mortality of B. glabrata, even in the lowest concentration tested, of $25 \mathrm{ppm}$. Regarding the fruit extract, there was variation in the mortality, depending on the concentration used (100, 75, 50 and $25 \mathrm{ppm})$. The snails that were in contact with the fruit extract had significant reduction in feeding and number of embryos in comparison to the control. The stem extract did not present molluscicidal activity nor had any influence on the feeding and oviposition abilities of B. glabrata, in the concentrations tested. In conclusion, the extracts of leaves and fruits of J. gossypiifolia investigated in this work show molluscicidal effect and may be sources of useful compounds for the schistosomiasis control.
\end{abstract}

KEYWORDS: Schistosomiasis; Snails; Biomphalaria glabrata; Jatropha gossypiifolia.

\section{INTRODUCTION}

Schistosomiasis is a chronic disease of great importance for public health in Brazil, due to its high prevalence, severity and clinical complications. Thus, it constitutes an important source of morbidity and mortality, especially in developing countries ${ }^{18,24}$.

In Brazil, Biomphalaria glabrata (Say, 1818), Biomphalaria tenagophila (d'Orbigny, 1835), Biomphalaria straminea (Dunker, 1848) are the species involved in transmission of schistosomiasis ${ }^{6}$. In the epidemiological chain of this parasitosis, B. glabrata is recognized as the best adapted intermediate host for transmission (Schistosoma mansoni Sambon, 1907), due to its wide geographical distribution and transmission efficiency ${ }^{21}$.

In areas of high prevalence, prevention strategies incorporate public health measures to improve sewage management and mass treatment programs. Travelers to endemic areas should be warned against fresh water exposure; however, this can be often difficult to avoid. Any individual with evidence of infection should be treated. The drug of choice is praziquantel given at a dose of $40 \mathrm{mg} / \mathrm{kg}$ [S. mansoni and Schistosoma haematobium (Bilhartz, 1852)] or $60 \mathrm{mg} / \mathrm{kg}$ (Schistosoma japonicum Katsurada, 1904) in two divided doses ${ }^{12}$.
To control schistosomiasis, besides the treatment of infected patients, it is very important to control snail populations as a way of reducing the risk of disease transmission ${ }^{20}$. Among molluscicides produced in laboratory, niclosamide (Bayluscide ${ }^{\circledR}$ ) is recognized as one of the agents most used in schistosomiasis control programs, with the aim of combating snails ${ }^{5}$. However, effective concentrations of this molluscicide concomitantly kill fish, which becomes a problem when it is used in areas where fishing is an important income and source of food for the population ${ }^{15}$. Moreover, this product is expensive and poorly biodegradable $\mathrm{e}^{3,10}$.

The Euphorbiaceae family is known for presenting species, such as Euphorbia milii var. splendens (Bojer ex Hook.) Ursch \& Leandri 1955 (Christ thorn) that not only have proven molluscicidal activity ${ }^{26}$, but they also do not have cytological action when used up to concentrations of $200 \mathrm{ppm}^{2}$. The species Jatropha gossypiifolia Linnaeus, 1753, commonly known as bellyache bush, belongs to this family and is native from tropical regions of the Americas ${ }^{1,27}$. Many parts of this plant have been used in folk medicine to treat various diseases, such as peptic ulcers, diabetes, cancer and diarrhea, and as a scar healing and diuretic agent ${ }^{14,22}$.

Various studies have been conducted in Northeastern Brazil, based

Núcleo de Imunologia Básica e Aplicada, Departamento de Biologia, UFMA, MA, Brazil.

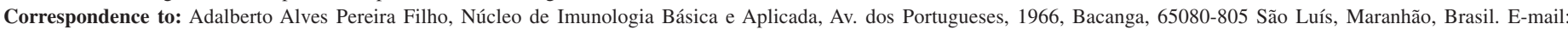
magneto_pa@hotmail.com 


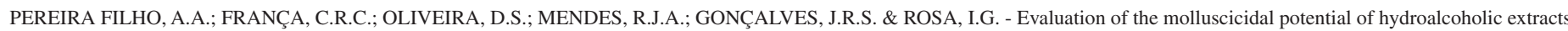
of Jatropha gossypiifolia Linnaeus, 1753 on Biomphalaria glabrata (Say, 1818). Rev. Inst. Med. Trop. Sao Paulo, 56(6): 505-10, 2014.

on the folk knowledge on the use of different plants, in order to validate their effect on a specific disease ${ }^{11}$. In view of the need to search for natural products with molluscicidal activity and low operational cost, the objective of the present study was to analyze the chemical components and evaluate the molluscicidal effect of hydroalcoholic extracts of the stem, leaves and fruit of $J$. gossypiifolia, taking into consideration the survival, feeding and oviposition ability of B. glabrata, in contact with these extracts.

\section{MATERIAL AND METHODS}

Assay on the molluscicidal activity of the plant extracts: The snails used in the tests were of the species Biomphalaria glabrata that had been collected in neighborhoods on the outskirts of the city of São Luís (S 2० 31' 48", W 44 18' 10") and were selected after quarantining, to ensure that they were negative for $S$. mansoni. The evaluation of the molluscicidal activity of the extracts was determined in accordance with the procedures previously described ${ }^{28}$. Snails with shells of $10-18 \mathrm{~mm}$ in diameter were exposed to the extracts for $24 \mathrm{~h}$. After exposure, the snails were rinsed and kept in dechlorinated water and were observed for four days. A control group was kept in dechlorinated water under the same experimental conditions. Four different concentrations were used for the extracts from each part of J. gossypiifolia: 100, 75, 50 and 25 $\mathrm{ppm}$. For each concentration, ten snails were used with three repetitions. The snails were handled in accordance with the principles of animal welfare in scientific experiments. Dead snails were those considered as showing discoloration of shells, immobility, exposure of the visceral mass, releasing hemolymph and lack of heartbeat, with the use of a stereoscopic microscope.

Plant Material: The plant material (leaves, fruit and stem) of Jatropha gossypiifolia L. was sampled in the neighborhood of Cohatrac I, in the municipality of São Luís, state of Maranhão, at 6:30 a.m., in September 2010. One sample was taken for preparation of exsiccate and sent to the Ático Seabra herbarium of the Federal University of Maranhão, where it is found under registration number 1293.

Preparation of the plant extract: Leaves, fruit and stem without impurities were selected and cut into pieces with scissors. These were then stored in large glass flasks separately for each plant part, and 92\% ethanol was added. The material was then macerated using a glass rod. The ratio of plant material to solvent was 1:4 for the fruit, 1:7 for the leaves and 1:4 for the stem. After fifteen days of maceration, the material was filtered in a simple funnel system using filter paper, and the hydroalcoholic extracts were concentrated in a rotary evaporator, to obtain the dry extracts.

Table 1

IC50 from extracts of different parts of the Jatropha gossypiifolia to Biomphalaria glabrata

\begin{tabular}{lc}
\hline Extract & IC50 \\
\hline Fruits & $53.60 \mathrm{ppm}$ \\
Leaves & $>100 \mathrm{ppm}$ \\
Steam & $<25 \mathrm{ppm}$ \\
\hline
\end{tabular}

Std. error $\log$ IC50 0.019
Phytochemical analysis: The phytochemical analysis on Jatropha gossypiifolia was performed by researching the following secondary metabolites: tannins, saponins, flavonoids and coumarins, which present high polarity; and steroids and triterpenoids, which present low polarity. The sequential route for prospecting for chemical components in the hydroalcoholic extract of J. gossypiifolia is in Table 2 . The concentrations of the compounds are described using crosses, where (+++) means strongly positive, $(++)$ moderately positive, $(+)$ weakly positive, $(-)$ traces and $(0)$ undetected, in accordance with the methodology described by MATOS (2009) $)^{13}$

Table 2

Methodology of prospecting the chemical constituents of hydroalcoholic extracts of Jatropha gossypiifolia

\begin{tabular}{|c|c|c|}
\hline Type Metabolite & $\begin{array}{l}\text { Quantity of } \\
\text { extract used } \\
\quad(\mathrm{mL})\end{array}$ & $\begin{array}{l}\text { Methodology } \\
\text { Matos (2009) }\end{array}$ \\
\hline Taninns & 4 & Reaction with ferric chloride \\
\hline Saponins & 80 & Foam test and precipitation \\
\hline Alkaloids & 80 & $\begin{array}{l}\text { Reacion with Hager, Mayer } \\
\text { and Dragendorff }\end{array}$ \\
\hline Flavonoids & 15 & $\begin{array}{l}\text { Test of } \Delta \mathrm{pH} \text { with } \mathrm{NaOH} \text { and } \\
\qquad \mathrm{H}_{2} \mathrm{SO}_{4}\end{array}$ \\
\hline Coumarins & 3 & Under fluorescent light UV \\
\hline $\begin{array}{l}\text { Steroids and triterpe- } \\
\text { noids }\end{array}$ & 80 & Test of Liberman-Buchard \\
\hline $\begin{array}{l}\text { Steroidal aglycones } \\
\text { and triterpenoids }\end{array}$ & 80 & $\begin{array}{c}\text { Hydrolysis of saponins with } \\
\text { subsequent testing Liberman- } \\
\text { Buchard }\end{array}$ \\
\hline
\end{tabular}

Verification of the effect of the hydroalcoholic extracts of Jatropha gossypiifolia on the feeding behavior of Biomphalaria glabrata: The surviving snails of each container (capacity of $2 \mathrm{~L}$ ) were fed with $6 \mathrm{~g}$ of lettuce, on a daily basis, after 24 hours of exposure to the extract. In order to assess the amount of lettuce that was consumed by the snails, the amount of food remaining in each 24 hours of the experiment was weighed using an analytical scale and was subtracted from the initial amount of food. It was found that if the lettuce were left under observation during four days, the lettuce would degrade and it would not be possible to measure the remaining quantity. The problem was solved by measuring the amount of water in the lettuce every 24 hours and renewing the amount withdrawn with a new lettuce, with the same amount as the previous one. Thus, the final amount of lettuce evaluated within four days was the sum of determining the quantity of lettuce evaluated every 24 hours.

Verification of the effect of the hydroalcoholic extracts of Jatropha gossypiifolia on oviposition by Biomphalaria glabrata: Before exposure, three polystyrene plates $(3 \times 4 \mathrm{~cm})$ were placed in each flask to investigate the number of eggs laid by the snails. At the end of the test, the polystyrene plates and the egg masses on the walls of the 


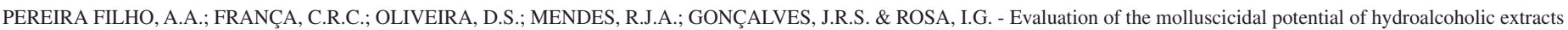
of Jatropha gossypiifolia Linnaeus, 1753 on Biomphalaria glabrata (Say, 1818). Rev. Inst. Med. Trop. Sao Paulo, 56(6): 505-10, 2014.

flask were removed using a spatula. The embryos were counted using a stereomicroscope by concentration and extract plant part.

Statistical analysis: In order to observe the effect of the extracts on the oviposition and feeding of $B$. glabrata, a descriptive statistical analysis was performed using means \pm standard deviations. The results relating to molluscicidal activity of the parts of the plant and tested concentrations were evaluated using the ANOVA Main Effect test, with a significance level of $\alpha=0.05$, to observe whether there was any difference between the types of extract analyzed and the type of concentration. The test was performed using the Statistic 7.0 software, StatSoft, Inc. Tulsa, USA. The IC50 values were calculated by nonlinear regression using the software GraphPad Prism 5.0. Significance was set to $p<0.05$.

\section{RESULTS}

Phytochemical analysis: The phytochemical study on J. gossypiifolia showed that, among the plant parts analyzed, the leaves presented the greatest variety of secondary metabolites. Catechins were present at low concentrations; saponins, triterpenoids and alkaloids were present at moderate concentrations; and tannins and steroids were present at high concentrations (Table 3).

Table 3

Secondary metabolites found in hydroalcoholic leaves, fruit and stems of Jatropha gossypiifolia

\begin{tabular}{lccc}
\hline $\begin{array}{l}\text { Secondary } \\
\text { metabolites }\end{array}$ & Leaves & Fruits & Stem \\
\hline Saponins & ++ & + & 0 \\
Taninns & +++ & ++ & - \\
Steroids & +++ & ++ & + \\
Triterpenoids & ++ & + & 0 \\
Alkaloids & ++ & ++ & 0 \\
Flavonoids & 0 & + & 0 \\
Coumarins & 0 & 0 & 0 \\
Catechins & + & 0 & 0 \\
\hline
\end{tabular}

L: $+++=$ Strongly positive $;++=$ Moderaly positive $+=$ Weakly positive; - = Traces; $0=$ undetected.

Conversely, the stem had lower amount of metabolites, presenting only steroids at low concentrations, and only traces of tannins. The leaves and fruit presented similar compositions of secondary metabolites, although the leaves showed some metabolites at higher concentrations. The fruit was the only part among the three plant parts analyzed that presented flavonoids. Details regarding the metabolites found and their concentrations, according to the part of the J. gossypiifolia plant, are shown in Table 3.

Although the phytochemical study that was performed aimed to seek high polarity metabolites to test them for water dwelling organisms like B. glabrata, information such as whether low polarity metabolites, like steroids and triterpenoids, are present or absent is essential, because it provides an idea of the type of saponin that exists in the extracts of the plant studied.
The aglycone part of the saponins found in the leaves and fruit were identified as triterpenoid saponins. The fruit presented a smaller amount than in the leaves.

Evaluation of the molluscicidal potential of the extracts from the stem, leaves and fruit of Jatropha gossypiifolia: The hydroalcoholic extracts of J. gossypiifolia leaves were lethal for Biomphalaria glabrata in all the concentrations tested. The $100 \%$ mortality rate was reached after 24 hours of exposure, for the concentrations of 100 and $75 \mathrm{ppm}$, and after 72 hours, for the concentrations of 50 and $25 \mathrm{ppm}$. Snail mortality was not observed in the control group or in the group treated with hydroalcoholic extract from the stem of J. gossypiifolia even in the highest concentration, $100 \mathrm{ppm}$. Regarding the group of animals in contact with hydroalcoholic extract of the fruits of J. gossypiifolia, there was variation in mortality, with different percentages, 100, 86, 40 and $26.6 \%$ to the concentrations of $100,75,50$ and 25 ppm, respectively (Fig. 1). This data showed that there were differences regarding the efficiency of the molluscicidal activities of the extracts of the three plant parts [F $=73.165, p<0.05]$ (Table 1$)$.

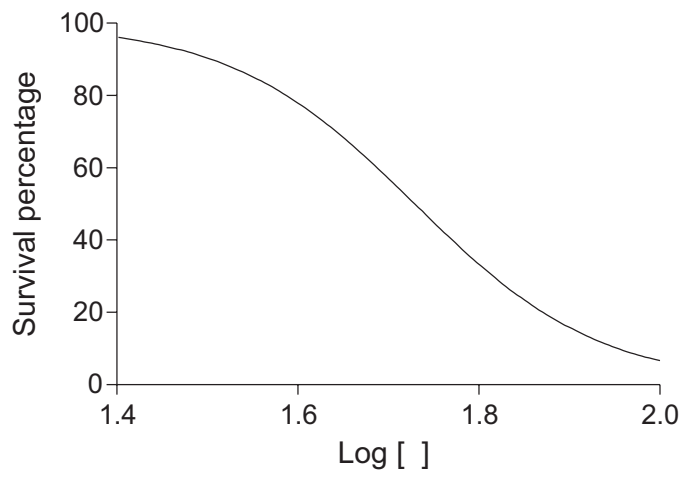

Fig. 1 - Regression analysis of the concentrations of the Jatropha gossypiifolia fruit extracts versus the percentage of survival of Biomphalaria glabrata.

The snails, when subjected to the hydroalcoholic extract of the leaves of J. gossypiifolia at the concentrations of 100, 75, 50 and 25 ppm, presented retraction of their cephalopodal mass, from which some groups were seen to release hemolymph. Concerning the hydroalcoholic extract from the fruits of $J$. gossypiifolia, the animals presented retraction of the cephalopodal mass without releasing hemolymph. With the hydroalcoholic extract of the stem of J. gossypiifolia, no activity on the cephalopodal mass was observed. In the control group, the snails remained alive.

Evaluation of the effect of the extracts from the stem, leaves and fruit of Jatropha gossypiifolia on the feeding ability of Biomphalaria glabrata: The feeding ability of the snails exposed to the hydroalcoholic extract of the leaves of $J$. gossypiifolia was completely suppressed, differently from the snails that were in contact with the hydroalcoholic extract from the stem, and also differently from the snail treated with the hydroalcoholic extracts from the fruits. The detailed results on the amounts of lettuce ingested by B. glabrata are shown in Table 4.

Evaluation of the effect of the extracts from the stem, leaves and fruit of Jatropha gossypiifolia on oviposition by Biomphalaria glabrata: The snails in contact with the solutions of the extract of leaves 


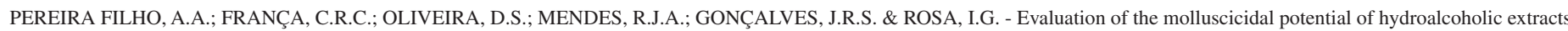
of Jatropha gossypiifolia Linnaeus, 1753 on Biomphalaria glabrata (Say, 1818). Rev. Inst. Med. Trop. Sao Paulo, 56(6): 505-10, 2014.

Table 4

Feeding capacity of Biomphalaria glabrata under different conditions

\begin{tabular}{lcc}
\hline Part of plant & $\begin{array}{c}\text { Concentration } \\
(\mathrm{ppm})\end{array}$ & $\begin{array}{c}\text { Quantity of ingested Lettuce (g) } \\
\text { [Mean and standard deviation] }\end{array}$ \\
\hline \multirow{4}{*}{ Fruits } & 100 & $0.0 \pm 0.0$ \\
& 75 & $0.7 \pm 0.1$ \\
& 50 & $4.0 \pm 0.2$ \\
& 25 & $4.3 \pm 0.32$ \\
\hline \multirow{3}{*}{ Stem } & 100 & $5.83 \pm 0.05$ \\
& 75 & $6.0 \pm 0.0$ \\
& 50 & $5.73 \pm 0.05$ \\
& 25 & $5.96 \pm 0.05$ \\
\hline
\end{tabular}

showed a high mortality rate, which had an influence on the impossibility of laying eggs. Moreover, even snails that showed no immediate mortality (during an exposure of $24 \mathrm{~h}$ ) did not perform the oviposition activity. Moreover, the snails in contact with the hydroalcoholic extract of the fruit showed a variation according to the concentration. There was no influence on the oviposition by B. glabrata when in contact with solutions of the extract of the stem. The mean and standard deviation of embryos posed by B. glabrata is shown in detail in Table 5 , by concentration and the plant extract.

\section{Table 5}

Effects of hydroalcoholic extracts of Jatropha gossypiifolia on the oviposition ability of Biomphalaria glabrata

\begin{tabular}{lcc}
\hline Part of Plant & $\begin{array}{c}\text { Concentration } \\
(\mathrm{ppm})\end{array}$ & $\begin{array}{c}\text { Quantity of embryos } \\
\text { [Mean and standard deviation] }\end{array}$ \\
\hline \multirow{4}{*}{ Fruits } & 100 & $0.0 \pm 0.0$ \\
& 75 & $105.66 \pm 5.68$ \\
& 50 & $252.33 \pm 3.21$ \\
& 25 & $370 \pm 2.64$ \\
\hline \multirow{3}{*}{ Stem } & 100 & $556.66 \pm 7.09$ \\
& 75 & $581.33 \pm 2.51$ \\
& 50 & $504.33 \pm 2.08$ \\
& 25 & $524.66 \pm 4.93$ \\
\hline
\end{tabular}

\section{DISCUSSION}

In Brazil, the first studies on molluscicides of plant origin have demonstrated the activity of aqueous extracts from Serjania sp. Linnaeus stems and fruit from Sapindus saponaria Linnaeus, popularly known as soap, on B. glabrata. This action was attributed to the saponins present in these plants ${ }^{16}$.

There are many species of tropical plants that have substances with molluscicidal activity, especially among the Asteraceae, Euphorbiaceae, Fabaceae and Phytolaccaceae families containing different types of substances of secondary plant metabolism that may have molluscicidal activity ${ }^{19}$.

Of the molluscicidal activity of 23 medicinal plants from the Northeastern region of Brazil on the snail B. glabrata, the extract from the leaves of Annona muricata Linnaeus was prominent at the concentration of $100 \mathrm{ppm}$, showing efficiency and resulting in the mortality of $100 \%$ of the snails tested ${ }^{11}$.

The action of extracts from 13 species in the Piperaceae family were studied on B. glabrata, including the following five species (Piper aduncum Linnaeus, $P$. crassinervium Kunth, $P$. cuyabanum C.DC, $P$. diospyrifolium Kunth and $P$. hostmannianum R.S), showing molluscicidal activity at concentrations ranging from 10 to $60 \mathrm{ppm}$ with $100 \%$ mortality ${ }^{17}$, which is a similar result among all concentrations of leaves of J. gossypiifolia in this study.

There are several reports on the efficiency of extracts of parts of $J$. gossypiifolia against various species of molluscs: Biomphalaria glabrata, Biomphalaria pfeifferi (Krauss, 1848), Bulinus globosus (Morelet, 1866) and Lymnaea luteola Lamarck, 1822. It demonstrated the ability of this plant to promote increased cardiac output on B. glabrata and Archachatina marginata (Swainson, 1821) 2,25.

In other snails, such as the Lymnaea acuminata Lamarck, 1822 species, plants of the Euphorbiaceae family (J. gossypiifolia, Euphorbia royleana Boiss, Euphorbia antisyphilitica Zucc. and Euphorbia lactea cristata Haw.) were studied. They were monitored for $24 \mathrm{~h}$ and showed LC50 with an average of $1.4 \times 10^{-6} 23$.

The elucidation of the molluscicidal activity requires studies that reveal details regarding the phytochemical profile of the plant ${ }^{5}$. The phytochemical approach not only facilitates the material to be studied, but also allows researchers to direct its use for various purposes, such as the development of new drugs and possible antibiotics, and even for some purposes like that of the present study, in seeking molluscicidal substances from plants.

As a natural defense, the plant produces substances (secondary metabolites) in greater diversity and intensity in its leaves and fruit, which are target organs for predators, such as insects and other herbivores.

Among the metabolites synthesized by plants, saponins are of interest because they present molluscicidal activity. They are substances that have an amphipathic structure formed by hydrophilic sugar residues bonded to a hydrophobic aglycone. In general, these metabolites present the ability to interact with sterols, which are present in the plasmatic membrane of cells, thus allowing ions and water to enter the cell and resulting in cell rupture, which releases hemoglobin ${ }^{8}$. Although the hemolytic properties are an outstanding characteristic of saponins, it is not common to all saponins and this is why the structural definition of aglycone in these compounds is a way of determining this trait?

Saponins can be classified in two types: steroidal and triterpenic. The triterpenic saponins consist of a group of natural compounds that present a wide spectrum of biological and pharmacological activities, among them, the ability to promote hemolysis of cells ${ }^{7}$. Maybe this explains the fact that there was a release of hemolymph from snails in contact 


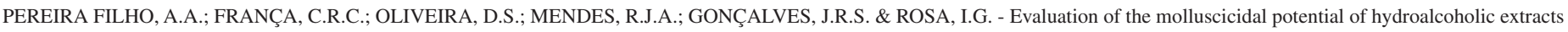
of Jatropha gossypiifolia Linnaeus, 1753 on Biomphalaria glabrata (Say, 1818). Rev. Inst. Med. Trop. Sao Paulo, 56(6): 505-10, 2014.

with the extract from leaves, reaction caused by the interaction between the amount of triterpenic saponins present in leaves and cells of the $B$. glabrata snails. The hemolytic properties of these extracts from leaves, evidenced in a test against the hemolysis of human erythrocytes, obtained positive results for all concentrations tested. The data is unpublished.

Although the phytochemical analysis showed that triterpenic saponins were present in the fruit of J. gossypiifolia, the absence of hemolytic activity among the snails can be attributed to the small amount of this substance found in this part of the plant. A similar profile was observed in plants tested against $B$. glabrata, which showed molluscicidal activity without promoting the release of hemolymph in the snails ${ }^{29}$.

Regarding the influence of the extracts on the feeding behavior of the snail, more studies are necessary, since previous studies conducted on plant extracts only aimed to ascertain the molluscicidal activity. The present study is the first on the feeding behavior. One possible explanation for the low food consumption of the snails in contact with extracts from leaves and fruit is that, besides the mortality caused by these extracts, locomotive ability was hindered, which in turn would have made it impossible for live snails to actively seek for their food.

Feeding is a fundamental factor for the development and proliferation of snails, and when it is affected, this can lead to losses with regard to the establishment of populations of B. glabrata. Thus, physiological mechanisms, such as the movement of planorbids in their constant search for food, are not only survival mechanisms, but they also influence the propagation and increase the population structure.

Biomphalaria glabrata snails are prolific, hermaphrodite animals that can either self-fertilize or crossbreed. They reach sexual maturity at 30 days of age, when they achieve the ability to lay eggs. The eggs are then kept in gelatinous masses, which may contain more than 100 eggs. Although they may be laid on any submersed solid structure and, almost on a daily basis ${ }^{4}$, this study observed that the extract from the fruit of $J$. gossypiifolia did not present an increased mortality effect, such as the extract from the leaves of J. gossypiifolia did. However, it reduced the oviposition ability of $B$. glabrata, in comparison to the control group and the stem extract.

Based on the results obtained using extracts from parts of $J$. gossypiifolia, there is a need to isolate the bioactive compounds of the extract from the leaves for future tests. In addition, in order to use this extract in the field, it is necessary to perform toxicity tests on non-target organisms, such as fish.

\section{RESUMO}

\section{Avaliação do potencial moluscicida de extratos hidroalcoólicos do caule, folhas e frutos de Jatropha gossypiifolia Linnaeus, $1753 \mathrm{em}$ Biomphalaria glabrata (Say, 1818)}

Estudou-se a ação dos extratos do caule, folhas e frutos de Jatropha gossypiifolia (Pinhão-roxo) sobre Biomphalaria glabrata analisando a sobrevivência, capacidade alimentar e de oviposição. Os extratos foram obtidos pela maceração das partes do vegetal em álcool etílico $92 \%$, evaporados até obter-se um resíduo seco e estudados fitoquimicamente. A atividade moluscicida em $B$. glabrata seguiu os procedimentos recomendados pela WHO (1965). A medida de quantidade de alimento ingerido e a oviposição foi realizada durante cada experimento. $\mathrm{O}$ extrato das folhas de J. gossypiifolia mostrou-se um forte agente moluscicida, promovendo $100 \%$ de mortalidade de B. glabrata mesmo na menor concentração testada, $25 \mathrm{ppm}$. Com o extrato dos frutos houve variação na mortalidade, de acordo com a concentração utilizada (100, 75, 50 e 25 ppm). Os caramujos em contato com o extrato dos frutos apresentaram quando comparado ao controle uma diminuição significativa nos comportamentos alimentares e de número de embriões. $\mathrm{O}$ extrato do caule não apresentou atividade moluscicida e nenhuma influência sobre a capacidade alimentar e de oviposição de B. glabrata nas concentrações testadas. Em conclusão, os extratos de folhas e frutos de J. gossypiifolia investigados neste trabalho apresentam efeito moluscicida e possivelmente podem ser fontes de compostos no controle da esquistossomose.

\section{ACKNOWLEDGEMENT}

To Mr. Francisco Moraes, a technician at FUNASA, who helped identifying the snail breeding sites; to the Federal University of Maranhão (UFMA) and the Research Support Foundation of Maranhão (FAPEMA) for their financial support.

\section{REFERENCES}

1. Abreu IC, Marinho ASS, Paes AMA, Freire SMF, Olea RS, Borges MOR, et al. Hypotensive and vasorelaxant effects of ethanolic extract from Jatropha gossypiifolia L. in rats. Fitoterapia. 2003;73:650-7.

2. Adewunmi CO. Natural products as agents of schistosomiasis control in Nigeria: a review of progress. Int J Crude Drug Res. 1984;22:161-6.

3. Andrews P, Thyssen J, Lorke D. The biology and toxicology of molluscicides, Bayluscide. Pharmacol Ther. 1982;19:245-95.

4. Brasil. Ministério da Saúde. Vigilância e controle de moluscos de importância epidemiológica: diretrizes técnicas. Programa de Vigilância e Controle da Esquistossomose (PCE). $2^{\mathrm{a}}$ ed. Brasília: Editora do Ministério da Saúde; 2008.

5. Cantanhede SPD, Marques AM, Silva-Souza N, Valverde AL. Atividade moluscicida de plantas: uma alternativa profilática. Rev Bras Farmacogn. 2010;20:282-6.

6. Carvalho OS, Amaral RS, Dutra LV, Scholte RG, Guerra MAM. Distribuição espacial de Biomphalaria glabrata, B. straminea e B. tenagophila, hospedeiros intermediários do Schistosoma mansoni no Brasil. In: Carvalho OS, Coelho PMZ, Lenzi HL, (organizadores). Schistosoma mansoni e esquistossomose: uma visão multidisciplinar. Rio de Janeiro: Editora Fiocruz; 2008.

7. Diniz RLL. Efeitos das saponinas triterpênicas isoladas de raízes da Ampelozizyphus amazonicus Ducke sobre a função renal. [Tese]. Belo Horizonte: Universidade Federal de Minas Gerais; 2006.

8. Karabaliev M, Kochev V. Interaction of solid supported thin lipid films with saponin. Sens Actuators B: Chem. 2003;88:101-5.

9. Kutchan TM. Ecological arsenal and developmental dispatcher. The paradigm of secondary metabolism. Plant Physiol. 2001;125:58-60.

10. Lopes TC, Gonçalves JRS, Souza NS, Moraes DFC, Amaral FMM, Rosa IG. Avaliação moluscicida e perfil fitoquímico das folhas de Caryocar brasiliensi Camb. Cad Pesq. 2011;18:23-30.

11. Luna JS, Santos AF, Lima MRF, Omena MC, Mendonça FAC, Bieber LW, et al. A study of the larvicidal and molluscicidal activites of some medicinal plants from northeast Brazil. J Ethnopharmacol. 2005;97:199-206. 
PEREIRA FILHO, A.A.; FRANÇA, C.R.C.; OLIVEIRA, D.S.; MENDES, R.J.A.; GONÇALVES, J.R.S. \& ROSA, I.G. - Evaluation of the molluscicidal potential of hydroalcoholic extracts of Jatropha gossypiifolia Linnaeus, 1753 on Biomphalaria glabrata (Say, 1818). Rev. Inst. Med. Trop. Sao Paulo, 56(6): 505-10, 2014.

12. MacConnachie A. Schistosomiasis. J R Coll Physicians Edinb. 2012;42:47-9.

13. Matos FJA. Introdução à fitoquímica experimental. $3^{\mathrm{a}}$ ed. Fortaleza: Editora da Universidade Federal do Ceará; 2009.

14. Mariz SR, Borges ACR, Melo-Diniz MFF, Medeiros IA. Possibilidades terapêuticas e risco toxicológico de Jatropha gossypiifolia L.: uma revisão narrativa. Rev Bras Plantas Med. 2010;12:346-57.

15. Oliveira-Filho EC, Geraldino BR, Coelho DR, De-Carvalho RR, Paumgarthen FJ. Comparative toxicity of Euphorbia milii latex and synthetic molluscicides to Biomphalaria glabrata embryos. Chemosphere. 2010;81:218-27.

16. Pinto C, Almeida, AF. Um novo método para a profilaxia da esquistossomose mansoni. Mem Inst Oswaldo Cruz. 1944;40:291-311.

17. Rapado LN, Nakano E, Ohweiler FP, Kato MJ, Yamaguchi LF, Pereira CAB, et al. Molluscicidal and ovicidal activities of plant extracts of the Piperaceae on Biomphalaria glabrata (Say, 1818). J Helminthol. 2011;85:66-72.

18. Raso G, Vounatsou P, McManus DP, N'Goran EK, Utzinger J. A Bayesian approach to estimate the age-specific prevalence of Schistosoma mansoni and implications for schistosomiasis control. Int J Parasitol. 2007;37:1491-500.

19. Rug M, Ruppel A. Toxic activities of the plant Jatropha curcas against intermediate snail hosts and larvae of schistosomes. Trop Med Int Health. 2000;5:423-30.

20. Ruiz ALTG, Magalhães EG, Magalhães AF, Faria AD, Amaral MCE, Serrano DR, et al. Avaliação da atividade tóxica em Artemia salina e Biomphalaria glabrata de extratos de quatro espécies do gênero Eleocharis (Cyperaceae). Rev Bras Farmacogn. 2005;15:98-102.

21. Scholte RGC, Carvalho OS, Malone JB, Utzinger J, Vounatsou P. Spatial distribuition of Biomphalaria spp., the intermediate host snails of Schistosoma mansoni, in Brazil. Geospat Health. 2012;6:S95-S101.
22. Silva SI. Euphorbiaceae da Caatinga: distribuição de espécies e potencial oleaginoso. [Tese]. São Paulo: Universidade de São Paulo; 1998

23. Singh A, Agarwal RA. Possibility of using latex of euphorbiales for snail control. Sci Total Environ. 1988;77:231-6.

24. Steinmann P, Keiser J, Bos R, Tanner M, Utzinger J. Schistosomiasis and wate resources development: systematic review, meta-analysis, and estimates of people at risk. Lancet Infect Dis. 2006;6:411-25.

25. Sukumaran D, Parashar BD, Rao KM. Toxicity of Jatropha gossypiifolia and Vaccaria pyramidata against freshwater snails vectors of animal schistosomiasis. Fitoterapia. $1995 ; 66: 393-8$.

26. Vasconcellos MC, Santos JAA, Silva IP, Lopes FEF, Schall VT. Molluscicidal activity of crown of Christ (Euphorbia splendens var. hislopii) (Euphorbiaceae) latex submitted to pH variation. Braz Arch Biol Technol. 2003;46:415-20.

27. Veiga AAS. Isolamento e quantificação de flavonóides e abordagem das atividades antioxidante e antimicrobiana de Jatropha gossypifolia L. [Dissertação]. Belém: Universidade Federal do Pará; 2008.

28. World Health Organization. Memoranda: molluscicide screening and evaluation. Bull World Health Organ. 1965;33:567-76.

29. Yamamoto MM, Kawano T, Young MCM, Haraguchi M, Hiroki K. Molluscicidal activity of three Brazilian plant species. Fitoterapia. 1996;57:59-62.

Received: 25 April 2013

Accepted: 26 March 2014 